\title{
Kontribusi Wakaf Lahan Produktif Untuk Meningkatkan Sosial-Ekonomi Masyarakat Islam Di Medan
}

\author{
Mukhlis \\ STAI Hubbulwathan Duri \\ E-mail:mukhlis@staihubbulwathan.id \\ Jl. Karya KM 7 Balai Makam Kec Bathin Solapan Kabupaten Bengkalis, Riau
}

\begin{abstract}
Abstrac
Research on the use of productive waqf land is directed at the first three components to people who need funds for their daily needs, the third free education, free health services. Waqf is part of an economic system that can help promote goodness and human values from back. Utilization of the results of productive waqf land management has a positive impact on the lives of Muslim communities in Medan City, North Sumatra.
\end{abstract}

\section{Keyword: Utilization, Productive Land, Waqf, Medan City}

\begin{abstract}
Abstrak
Penelitian tentang pemanfaatan tanah wakaf produktif ini diarahkan pada tiga komponen pertama kepada masyarakat yang membutuhkan dana untuk kebutuhan hidup sehari-hari, pemberian pendidikan gratis ketiga, layanan kesehatan gratis.Wakaf merupakan bagian dari sistem ekonomi yang dapat membantu mengangkat kebaikan dan nilai-nilai kemanusiaan dari belakang. Pemanfaatan hasil pengelolaan lahan wakaf produktif berdampak positif bagi kehidupan masyarakat muslim di Kota Medan, Sumatera Utara.
\end{abstract}

Keyword: Pemanfaatan, Wakaf, Tanah Produktif, Kota Medan

\section{Pendahuluan}

Wakaf merupakan aspek ekonomi dan distribusi khusus dalam sistem Islam, merupakan konsep amal yang memberikan pahala terus menerus kepada orang yang melakukan wakaf. Keistimewaan amalan wakaf terdiri dari amal jariah, pemberian bantuan gratis yang memiliki nilai sosial tinggi dan bimbingan kepada umat Islam dari hasil wakaf. Tanah wakaf merupakan salah satu wakaf yang memiliki peran penting bagi kesejahteraan masyarakat. Pengelolaan endowment yang profesional dapat mengatasi segala bentuk kerusakan ekonomi dalam kehidupan masyarakat. Pengelolaan dan pemberdayaan wakaf yang produktif dapat mengurangi kemiskinan, meningkatkan tingkat pendapatan, pendidikan dan kesehatan masyarakat. Manfaat pengelolaan lahan wakaf adalah hasil yang cukup baik, sehingga dilakukan secara profesional dan dapat memberikan hasil yang maksimal. Wakaf adalah salah satunyasebuah instrumen ekonomi 


\section{Kontribusi Wakaf Lahan Produktif Untuk Meningkatkan \\ Sosial-Ekonomi Masyarakat Islam Di Medan}

Mukhlis

Islam yang memadukan aspek spiritual dan material yang merupakan institusi pembangunan ummat yang sangat penting dalam mengembangkan ekonomi Islam ummah. Pembangunan adalah proses bisnis untuk mengatur suatu masyarakat atau negara menuju kemajuan dan meningkatkan kualitas hidup manusia baik individu maupun masyarakat, pembangunan ekonomi merupakan bagian dari aspek pembangunan tersebut. Arah utama perkembangan Islam adalah, mengagungkan martabat manusia di dunia ini dan di akhirat. Pencapaian martabat manusia meliputi keberhasilan membangun manusia dalam segala dimensi kebutuhan alaminya, semoga kehidupannya berkualitas dalam aspek kehidupan termasuk kemajuan ekonomi.(Nik Mustafa Haji Nik Ahmad, 1999) Sebagian besar penduduk Indonesia pada umumnya tanah merupakan posisi yang sangat penting dalam kehidupan sehari-hari terutama bagi penduduk desa (desa) yang pekerjaan utamanya adalah bercocok tanam, berkebun atau bercocok tanam, tanah merupakan aset utama dan satu-satunya bagi sebagian orang. (Depag RI, 2004). Faktor-faktor penyebab terjadinya krisis ekonomi tahun 1997 di Indonesia sehingga meningkatkan angka kemiskinan di Indonesia khususnya di Kota Medan adalah:Pertama, saham utang luar negeri yang sangat besar dan umumnya berjangka pendek, telah menciptakan kondisi "ketidakstabilan". Ini adalah sikap yang lebih percaya diri dan para menteri di bidang ekonomi serta perbankan sendiri menghadapi masalah hutang.Kedua, terkait masalah di atas, adalah banyaknya kelemahan sistem perbankan di Indonesia.Dengan lemahnya sistem perbankan, masalah utang swasta luar negeri menjadi masalah perbankan dalam negeri.Ketiga, sejalan dengan perubahan politik saat ini, maka persoalan pemerintahan secara langsung berkembang menjadi persoalan ekonomi pula.Keempat, perkembangan situasi politik semakin gencar akibat rentetan krisis ekonomi, sekaligus berdampak pada krisis ekonomi itu sendiri. (Devi Putran, 2020)

Dalam pandangan Islam terjadi keterpurukan ekonomi akibat sistem riba. "Factor Pricing and Income Distribution from AnIslamic Perspective") yang dimuat dalam Journal of Islamic Economics, menyebutkan bahwa pelarangan riba dalam perekonomian setidaknya disebabkan oleh empat alasan: Pertama, sistem ekonomi ribawi telah menimbulkan ketidakadilan di masyarakat, terutama bagi para kapitalis (bank) yang pasti mendapat untung terlepas dari apakah peminjam menghasilkan uang atau tidak.Kedua, sistem ekonomi ribawi juga menjadi penyebab utama ketidakadilan antara investor dan peminjam.Ketiga, sistem ekonomi ribawi menghambat kapitalis karena semakin tinggi minat masyarakat maka semakin kecil kecenderungan masyarakat untuk 
menanamkan properti. Keempat, bunga dianggap sebagai tambahan biaya produksi bagi pengusaha yang menggunakan modal pinjaman. (Agustianto, 2020)

Untuk itu ada tiga dampak utama masalah bunga sebagai berkut: Bunga membutuhkan pertumbuhan ekonomi yang tidak ada habisnya dan bahkan masyarakat yang tidak membaik, Bunga mendorong persaingan antar pelaku ekonomi, Bunga membuat properti terfokus pada tangan minoritas dengan cara tertentu, mengambil keuntungan (taxing) dari kelompok mayoritas (Ahamed Kameel Mydin, 2010). Dengan demikian dapat dipahami bahwa keterpurukan ekonomi pada masa krisis ekonomi Indonesia tahun 1997 berdampak luas sehingga masyarakat kehilangan pekerjaan, pengangguran yang ditimbulkan cukup besar sehingga menyebabkan penduduk menjadi miskin. Keadaan ini memberi pertanda bahwa ketidakpastian keadaan negara berdampak pada sosial ekonomi masyarakat. Jelas terlihat bahwa program kependudukan Kota Medan seperti yang dilakukan di daerah lain meliputi: pengendalian kelahiran, penurunan angka kematian bayi dan anak, pemerataan harapan hidup lansia dan pengembangan penduduk potensial sebagai modal pembangunan yang harus ditingkatkan. Pembangunan penduduk dengan meningkatkan keberlanjutan sumber daya dan fungsi alam lingkungan hidup sehingga mobilitas dan persebaran penduduk tercapai secara optimal. Mobilitas dan distribusi penduduk yang optimal, yang didasarkan pada keseimbangan antara jumlah penduduk yang tidak didukung oleh lingkungan dan pembangunan, menimbulkan permasalahan sosial yang kompleks, dimana masyarakat menjadi beban bagi lingkungan dan sebaliknya.

Badan Pusat Statistik (BPS) Sumut mencatat, Perekonomian Sumut pada tahun 2017 tumbuh sebesar 5,12 persen, sedikit melambat dibandingkan pertumbuhan tahun 2016 yang mencapai 5,18 persen. Pertumbuhan ini terjadi di semua bidang bisnis komunitas. Pengadaan listrik dan gas menjadi sektor bisnis dengan pertumbuhan tertinggi 8,72 persen (Tran Tribunnews, 2020)Pertumbuhan ekonomi saat ini, kontribusi terbesar berasal dari sektor telekomunikasi, pengangkutan dan perdagangan. Sektor ini tidak banyak mempekerjakan atau mempekerjakan banyak tenaga kerja di Kota Medan, sedangkan pencarian kerja dari tahun ke tahun semakin meningkat seiring dengan perkembangan penduduk. Disini peneliti menjelaskan kembali bahwa data yang diperoleh baik dalam bentuk diagram maupun diagram menggunakan data lama dan peneliti perlu menjelaskan bahwa data dalam bentuk tersebut tidak ada perubahan data karena adanya 


\section{Kontribusi Wakaf Lahan Produktif Untuk Meningkatkan \\ Sosial-Ekonomi Masyarakat Islam Di Medan}

Mukhlis

perubahan datadilakukan dalam kurun waktu 5 tahun hingga data baru tidak dapat diumumkan karena harus sejalan dengan pusat data.

Dengan demikian, wakaf berperan besar dalam mengatasi permasalahan sosial masyarakat. Dalam kaitan ini, upaya yang dilakukan pemerintah antara lain mendukung pemekaran dan kontribusi aktif yang potensial seperti, Lembaga Wakaf, Zakat, Infaq dan Shadaqah serta pengelolaan lahan wakaf produktif. Dengan wakaf tanah produktif, hasil yang diperoleh juga dapat digunakan untuk kebutuhan umat muslim. Dalam konteks pembangunan umat Islam, sumbangan tanah wakaf produktif saat ini merupakan salah satu penerus untuk meningkatkan pertumbuhan dan perkembangan ekonomi serta kesejahteraan umat Islam, berpotensi memberikan keuntungan berlipat ganda jika dikelola dengan baik dan profesional.

Secara umum penguasaan lahan produktif yang merupakan kontribusi yang memberikan hasil positif apabila pengelolaannya dilakukan dengan baik oleh umat Islam seperti di Kota Medan (Sumatera Utara) secara maksimal. Dari data yang tertera, ternyata seluruh lahan wakaf berada di Sumatera Utara dengan luas 100.898.713 M2 dan total luas lahan wakaf yang sudah dimanfaatkan di Negara Sumatera Utara adalah 4.414.817 M2 yaitu 4\% (persentase) dari total lahan wakaf ini berarti ada 96.483 .896.M2 96\% (persentase) lahan wakaf di Sumatera Utara yang belum dimanfaatkan. (Kementerian Agama RI, 2005). Banyak tanah wakaf yang tidak dikelola dengan baik, sehingga dengan konsep pemanfaatan produktif tanah wakaf dapat memberikan efektifitas bagi perkembangan ekonomi syariah dan juga dapat disalurkan ke sektor ekonomi real estate lainnya dan dapat memudahkan kehidupan umat islam antara lain membantu meningkatkan pendapatan umat islam, meningkatkan standar pendidikan yang memiliki daya saing yang kuat dan maju serta derajat kesehatan yang lebih baik. Dengan terselenggaranya donasi berupa wakaf tanah produktif yang dapat dikelola dengan baik dapat meningkatkan taraf sosial ekonomi masyarakat muslim di Kota Medan (Sumatera Utara).

Dalam melaksanakan pengelolaan wakaf tanah produktif baik berhasil maupun tidak, pihak-pihak yang berperan aktif dalam pengelolaan sumbangan harta wakaf produktif adalah bagian dari pengawas wakaf, yaitu seseorang, sekelompok orang atau badan hukum yang ditugaskan oleh wakaf untuk mengelola harta benda berupa tanah. . Keunggulan dari harta endowmen ini, mampu menciptakan inspektur secara profesional sangat dibutuhkan bahkan menempatkan mereka pada peran utama dalam pengelolaan 
endowment. Oleh karena itu, di bawah kendali Nadzir, merupakan tanggung jawab dan kewajiban untuk memelihara, memelihara dan mengembangkan wakaf serta menyalurkan hasil dan manfaatnya (Kementerian Agama RI, 2005).

\section{Tinjauan Teoritik}

Wakaf dalam arti etimologis: wakaf diambil dari kata kerja waqafa, yaqfu, waqfan artinya berhenti, diam ditempat, atau menahan, (Depag RI, 2006)Untuk mengungkapkan terminologi wakaf, para ahli hukum menggunakan dua kata: habas dan wakaf. Oleh karena itu, kata-kata seperti habasa atau ahbasa atau awqafa sering digunakan untuk mengungkapkan kata kerja. Sedangkan wakaf dan habas adalah kata benda dan bentuk jamaknya adalah wakaf, ahbas dan mahbus. Dalam kamus Al-hadits disebutkan bahwa alhabsu berarti al-man'u (mencegah atau melarang) dan al imsak (menahan) seperti dalam kalimat habsu as-syai '(menahan sesuatu) Waqfuhu la yuba'wa la yurats (wakaf bukan diperdagangkan dan tidak diwariskan) (Mundzir Qahaf, 2000)Pengertian wakaf menurut PP Indonesia Nomor 28 Tahun 1977 tentang Pemberian tanah milik Pasal 1 yaitu (1) Wakaf adalah perbuatan hukum seseorang atau badan hukum yang memisahkan sebagian hartanya berupa tanah yang dimiliki dan dilembagakan untuk selamanya untuk kepentingan keagamaan atau kepentingan umum lainnya., sesuai dengan ajaran Islam (UU Wakaf No. 41, 2004).

Hal ini terlihat dari rumusan makna wakaf dalam Undang-Undang Nomor 41 Tahun 2004 tentang wakaf, yaitu: Wakif adalah perbuatan hukum wakif untuk memisahkan dan atau menyerahkan sebagian hartanya untuk diurus selamanya atau untuk jangka waktu tertentu sesuai dengan kepentingannya untuk keperluan ibadah dan atau kesejahteraan umum menurut syariah. "Pengelolaan wakaf tanah produktif dapat memberikan solusi dalam pembangunan pemanfaatan tanah abadi yang dikelola sehingga dapat dimanfaatkan untuk masyarakat miskin. Dengan upaya memperluas lahan wakaf yang biasanya digunakan sebagai tempat ibadah, sekolah, rumah sakit dan balai pertemuan kedepan, penggunaan tanah wakaf dapat digunakan sebagai nilai ekonomi dan tumbuh sebagai hasil dari penggunaan tanah untuk kepentingan yang kurang mampu atau miskin.

\section{Hukum Dasar Wakaf}

Secara khusus tidak ditemukan nash al-quran maupun hadits yang secara eksplisit menyatakan dasar hukum yang melegitimasi anjuran wakaf. Namun secara 


\section{Kontribusi Wakaf Lahan Produktif Untuk Meningkatkan \\ Sosial-Ekonomi Masyarakat Islam Di Medan}

Mukhlis

umum ada banyak ayat Alquran dan hadits yang menganjurkan keyakinan mukmin untuk menyisihkan sebagian dari kekayaan berlebih yang digunakan untuk proyek produktif bagi masyarakat,Bukti hukum dari Alquran:Karena kami tahu, bahwa TUHAN itu maha besar dan firman-Nya itu benar.

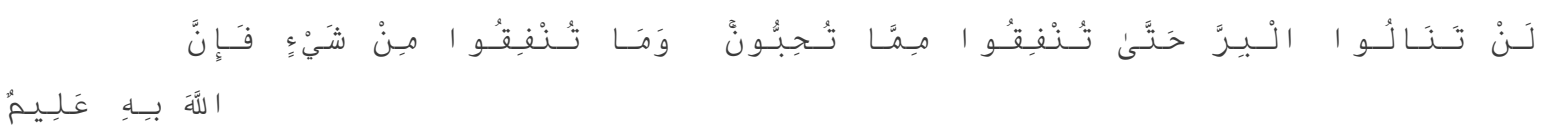

Artinya: "Anda tidak pernah mencapai kebajikan (sempurna), sebelum Anda menghabiskan sebagian dari properti yang Anda cintai. Dan apapun yang kamu belanjakan, sesungguhnya Allah mengetahuinya. "(Q.SAliImran93)

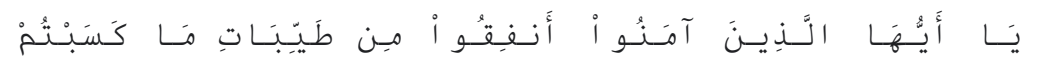

Artinya: "Hai kamu yang beriman, belanjakan (di jalan Allah) sebagian hasil baik dari jerih payahmu" (QS: Albaqarah: 267)

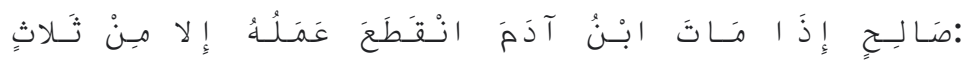

Berarti; 'Ketika seseorang meninggal maka perbuatannya dipotong kecuali tiga hal, yaitu: amal jariah, atau ilmu yang berguna atau anak yang bertakwa "(HR. Muslim) (Kementerian Republik Indonesia, 2005)

\section{Rukun Dan Kondisi Wakaf}

Para ahli hukum sepakat bahwa wakaf harus memenuhi rukun dan syarat tertentu, hanya saja mengenai jumlah rukunnya, terdapat perbedaan pendapat di antara para ahli hukum. Menurut Mazhab Hanafi, pilar wakaf hanya satu, yaitu sighat (pernyataan pemberian wakaf) sedangkan mayoritas ulama yaitu dari mazhab Syafi'I Maliki dan Hambali menyatakan bahwa pilar wakaf memiliki empat hal sebagai berikut: Wakif, yaitu orang yang memberkahi, Maukuf, yaitu barang / harta yang diberkahi, Maukuf 'alaih, yaitu target yang berhak menerima hasil atau manfaat wakaf, Sighat, yaitu pernyataan wakif sebagai kemauan untuk memberkahi hartanya (Depag RI, 2005). Dari pendapat mayoritas ulama dapat dianalisa bahwa para ulama menekankan pada harta wakaf yang memiliki nilai dan manfaat yang begitu besar untuk dikembangkan dan diproduksi untuk kemaslahatan masyarakat luas. 


\section{Metode Penelitian}

Metode penelitian ini dilakukan dengan metode penelitian Mixed Methodology dimana kami menggunakan lokasi penelitian kuantitatif dan kualitatif yang dilakukan oleh Kota Medan. Dalam penelitian ini mengacu pada buku, jurnal pengadaan karya ilmiah yang berkaitan dengan masalah wakaf dan pemanfaatannya. Dan juga survei dengan menggunakan responden yang merupakan penerima manfaat dari pendapatan tanah wakaf produktif. Terkait dengan itu akan dijelaskan tentang responden yang terdiri dari jenis kelamin, umur, status, tanggungan, pendidikan, pendapatan. Ditinjau dari jenis kelamin sebanyak 135 responden berjenis kelamin laki-laki 90 (66,7\%) dibandingkan 45 orang (33,3\%) perempuan. Untuk penelitian selanjutnya diberikan jenis responden berdasarkan jenis kelamin seperti yang dijelaskan pada tabel berikut:

Tabel 1

Jenis Kelamin Responden

\begin{tabular}{|c|c|c|}
\hline & Frekuensi & Persentase (\%) \\
\hline Laki-Laki & 90 & 66,7 \\
\hline Wanita & 45 & 33,3 \\
\hline Total & 135 & 100 \\
\hline
\end{tabular}

Dimana umat Islam Kota Medan memiliki potensi tanah wakaf yang besar, maka dapat diamati bahwa pada umumnya masyarakat muslim yang mayoritas memiliki harta benda seperti tanah, uang dan harta benda berharga lainnya, juga memiliki tingkat sosial masyarakat yang tinggi. Pengembangan dan pengelolaan lahan wakaf produktif di Kota Medan berpotensi untuk meningkatkan taraf hidup masyarakat muslim di Kota Medan ke arah yang lebih baik. Penelitian ini juga dilakukan pada 3 (tiga) Kecamatan di wilayah Kota Medan yang merepresentasikan hasil penelitian secara keseluruhan seperti tabel dibawah ini: 


\section{Kontribusi Wakaf Lahan Produktif Untuk Meningkatkan \\ Sosial-Ekonomi Masyarakat Islam Di Medan \\ Mukhlis}

Tabel 2

Data lokasi lahan yang digunakan sebagai lokasi penelitian

\begin{tabular}{|c|c|c|c|c|c|c|c|c|c|c|c|c|}
\hline \multirow{5}{*}{$\begin{array}{l}\text { Lokasi } \\
\text { Penelitian } \\
\text { Di Distrik }\end{array}$} & \multirow{4}{*}{\multicolumn{2}{|c|}{$\begin{array}{l}\text { Total Tanah } \\
\text { WaqafParsil }\end{array}$}} & \multirow{4}{*}{\multicolumn{2}{|c|}{ Sertifikat }} & \multicolumn{8}{|c|}{ Status Tanah Sertifikat } \\
\hline & & & & & \multicolumn{6}{|c|}{ Belum bersertifikat } & \multirow{3}{*}{\multicolumn{2}{|c|}{ Jumlah }} \\
\hline & & & & & \multirow{2}{*}{\multicolumn{2}{|c|}{$\begin{array}{c}\text { Dalam } \\
\text { Proses } \\
\text { BPN }\end{array}$}} & \multicolumn{4}{|c|}{ Belum Proses BPN } & & \\
\hline & & & & & & & \multicolumn{2}{|c|}{$\begin{array}{l}\text { Sudah } \\
\text { AIW }\end{array}$} & \multicolumn{2}{|c|}{$\begin{array}{l}\text { Belum } \\
\text { AIW }\end{array}$} & & \\
\hline & $\mathrm{L}$ & $\begin{array}{l}\text { Luas } \\
\left(\mathrm{M}^{2}\right)\end{array}$ & $\mathrm{L}$ & $\begin{array}{l}\text { Luas } \\
\left(\mathrm{M}^{2}\right)\end{array}$ & $\mathrm{L}$ & $\begin{array}{c}\mathrm{L} \\
\mathrm{M} \\
2\end{array}$ & $\mathrm{~L}$ & $\begin{array}{l}\mathrm{L} \\
\mathrm{M}^{2}\end{array}$ & $\mathrm{~L}$ & $\begin{array}{l}\text { Luas } \\
\mathrm{M}^{2}\end{array}$ & Lokasi & $\begin{array}{c}\text { Luas } \\
\mathrm{M}^{2}\end{array}$ \\
\hline 2 & 3 & 4 & 5 & 6 & 7 & 8 & 9 & 10 & 11 & 12 & 13 & 14 \\
\hline Medan Area & 102 & $197,084,00$ & 80 & $70,732,68$ & 22 & - & - & - & - & - & - & - \\
\hline Medan Kota & 66 & $115,000,00$ & 35 & $18,622,90$ & 16 & - & - & - & - & - & - & - \\
\hline Medan Polonia & 20 & $59,100,00$ & 10 & $8,396,00$ & 4 & - & - & - & - & - & - & - \\
\hline JUMLAH & 188 & $\mathbf{3 7 1 , 1 8 4 , 0 0}$ & 125 & $\mathbf{9 7 , 7 5 1 , 5 8}$ & 44 & & $\mathbf{O}$ & & $\mathbf{O}$ & & $\mathbf{O}$ & \\
\hline
\end{tabular}

Sumber: Derektori Tanah Wakaf Data Pengurusan Tanah Wakaf Kota Medan 2007

Adapun 3 (tiga) kecamatan di Kota Medan yaitu: Kecamatan Medan Area, Kecamatan Kota Medan dan Kecamatan Medan Polonia, dimana Kecamatan Medan Luas: tanah wakaf 102 Parsil dengan luas 197.084.00 M2, Kota Medan Kecamatan: tanah wakaf berlokasi 66 Parsil dengan luas 115.000,00 M2 dan Kecamatan Medan Polonia: tanah wakaf terletak 20 Parsil dengan luas 59.100,00 M2. Merupakan tempat yang memiliki potensi lahan wakaf produktif sebagai wujud nyata lahan wakaf yang dikembangkan oleh nazir untuk kesejahteraan masyarakat di kota kecil.

\section{Hasil Dan Pembahasan}

Potensi wakaf dikelola dengan baik berdasarkan kaidah-kaidah profesional, sehingga memberikan dampak positif yang sangat besar dalam kehidupan masyarakat muslim. Beban permasalahan yang dihadapi saat ini, karena krisis ekonomi dapat diselesaikan secara fundamental dan komprehensif melalui sistem pemungutan, pengelolaan dan pemajuan harta wakaf dalam lingkup nasional. (Achmad Djunaidi, 2005)

Kehidupan sosial antar komunitas lapangan berdampak positif pada kehidupan komunitas bersama. Sikap membantu sesama dalam komunitas miskin adalah konsep Islam. Masyarakat yang memiliki harta kekayaan yang banyak di kalangan umat Islam wajib meringankan beban hidup fakir miskin dengan mendonasikan hartanya berupa Zakat, Infak, Sedekah dan Wakaf yang nantinya dikelola oleh nazhir dan disumbangkan kepada yang membutuhkan. Selanjutnya untuk mewujudkan harta wakaf yang merupakan 
salah satu alat untuk meringankan beban kehidupan masyarakat dari golongan miskin, secara terus menerus pengelolaan harta wakaf dapat mengurangi kemiskinan secara adil dan merata.

Dari hasil Wawancara dengan Romo Panigoran Siregar menjelaskan tentang penggunaan tanah wakaf produktif: Bahwa penerimaan hasil pengelolaan tanah wakaf produktif selalu sejalan dengan pemberian donasi kepada masyarakat yang membutuhkan serta sering memberikan donasi tiga bulan serta bantuan keuangan sebesar Rp. 100.000, sampai dengan Rp. 200.0oo untuk kebutuhan anak SD, Sekolah Menengah Pertama dan Atas (SMP / Madrasah dan SMU / Aliyah) dan masyarakat miskin di kota Medan. Senada dengan Pimpinan Badan Amil Zakat Infak dan Shadaqah Bapak Maratua Simanjuntak memberikan respon positif terhadap penggunaan tanah wakaf produktif menurutnya menjelaskan bahwa lembaga yang dipimpinnya merupakan lembaga yang selalu mengembangkan dana abadi untuk kebutuhan, pendidikan, kesehatan bagi masyarakat miskin. Bantuan yang mana secara bergiliran dan terus menerus kepada pihak-pihak yang menerima bantuan dari penggunaan tanah wakaf seperti beasiswa pendidikan bagi siswa yang diberikan setiap tahun sebesar Rp. 600.00o.

Pemanfaatan Wakaf Tanah Produktif di KotaMedan memberikan penilaian yang positif, Pada penelitian tersebut yaitu Kontribusi Lahan Produktif terhadap Peningkatan Sosial Ekonomi Umat Islam di Medan Sumatera Utara telah diteliti dengan baik menggunakan metode penelitian metode lapangan menunjukkan bahwa penggunaan tanah wakaf produktif bersama untuk kemaslahatan umat. Hasil pemanfaatan tanah wakaf produktif diarahkan untuk kebutuhan masyarakat umum khususnya anak-anak kurang mampu, mereka diberikan beasiswa untuk pendidikannya dan dibantu melanjutkan studi, memberikan pelayanan kesehatan kepada fakir miskin akan mendapatkan pelayanan rumah sakit, keramahan anak yatim piatu di panti asuhan, pembangunan bagi yang ada di Kota Medan. Begitu pula dengan peningkatan perekonomian masyarakat, pemberian modal usaha, subsidi benih pertanian dan pupuk juga menipu para pelaku usaha rumah tangga (UKM) di industri kerajinan ibu-ibu.

\section{Pemberian Lahan Produktif untuk Mengatasi Kemiskinan di Medan}

Kemiskinan adalah keadaan ekonomi seseorang yang kekurangan kebutuhan dasar terpenting dalam hidupnya yaitu uang, pangan, air, pendidikan, kesehatan dan papan. Di antara indikator kemiskinan adalah seseorang yang buta huruf, tidak 
berpendidikan atau kurang memiliki keterampilan. Menurut Said Siddiqui, formula Bank Dunia untuk mengurangi kemiskinan dengan meningkatkan pertumbuhan ekonomi dan bantuan langsung kepada yang membutuhkan telah ditemukan dalam ajaran Islam itu sendiri berdasarkan pembiayaan Islam, zakat dan pinjaman tanpa bunga atau qard alhasan. (Asmak Ab Rahman, 2009)

Masyarakat Kota Medan yang masih hidup di bawah garis kemiskinan, disebabkan oleh distribusi kekayaan dan pendapatan yang tidak adil. Lingkaran kemiskinan bersifat struktural sehingga upaya penanggulangannya harus dilakukan secara sistematis dan komprehensif, tidak hanya secara spontan tetapi harus terukur. Dari berbagai permasalahan yang ada, masalah kemiskinan dan pembagian pendapatan menjadi isu utama yang harus diatasi, diantaranya kemerosotan tingkat kesejahteraan di negara berkembang, krisis yang menimpa perekonomian dunia terkait dengan sistem perekonomian saat ini. dalam perekonomian negara yang ada, khususnya sistem ekonomi Islam. (Muhammad Yasir Nasution, 2002) Kemiskinan merupakan masalah yang sangat serius yang dihadapi oleh Negara Indonesia dimana sebagian besar penduduknya berada dalam kemiskinan. Hampir 40\% penduduk Indonesia hidup sedikit di atas garis kemiskinan nasional dan berpenghasilan kurang dari US \$ 2 per hari. Berbagai program penanggulangan kemiskinan telah dilaksanakan oleh Pemerintah dan lembaga swadaya masyarakat (swasta, LSM, Donor Agent, dll. (A.Syafii Maarif et al., 2007).

\section{Tabel 3}

\section{Garis Kemisikinan dan Penduduk Miskin di Kota Medan, 2010-2017}

\begin{tabular}{|c|c|c|}
\hline$(1)$ & $(2)$ & $(3)$ \\
\hline 2010 & 331659 & 212.30 \\
\hline 2011 & 373619 & 204.19 \\
\hline 2012 & 384608 & 201.06 \\
\hline 2013 & 396112 & 209.69 \\
\hline 2014 & 401417 & 200.32 \\
\hline 2015 & 420208 & 207.50 \\
\hline 2016 & 460685 & 206.87 \\
\hline $\mathbf{2 0 1 7}$ & $\mathbf{4 9 1 4 9 6}$ & $\mathbf{2 0 4 . 2 2}$ \\
\hline
\end{tabular}

Sumber : BPS Sumatera Utara 


\section{Tabel 4}

\section{Gini Rasio, Indeks Kedalaman (P1) dan Keparahan (P2)} Kemiskinan di Kota Medan

\begin{tabular}{|c|c|c|c|}
\hline $\begin{array}{c}\text { Tahun } \\
\text { Year }\end{array}$ & $\begin{array}{c}\text { GiniRasio } \\
\text { GiniRatio }\end{array}$ & $\begin{array}{c}\text { Indeks } \\
\text { Kedalaman/ } \\
\text { DepthIndex }\end{array}$ & $\begin{array}{c}\text { Indeks } \\
\text { Keparahan/ } \\
\text { Severity Index }\end{array}$ \\
\hline$(1)$ & $(2)$ & $($ P1) & $($ P2) \\
\hline 2010 & 0,3610 & 1,57 & $(4)$ \\
\hline 2011 & 0,3269 & 1,70 & 0,42 \\
\hline 2012 & 0,3940 & 1,49 & 0,49 \\
\hline 2013 & 0,3959 & 1,52 & 0,37 \\
\hline 2014 & 0,3220 & 1,33 & 0,34 \\
\hline 2015 & 0,3739 & 1,21 & 0,28 \\
\hline 2016 & 0,3328 & 1,51 & 0,24 \\
\hline $\mathbf{2 0 1 7}$ & 0,3520 & 1,56 & 0,41 \\
\hline
\end{tabular}

BPS: Sumatera Utara Kota Medan Dalam Angka

Fenomena kemiskinan di Kota Medan yang bersifat multikompleks disebabkan dari faktor struktural merupakan faktor utama penyebab upaya penurunan pendapatan yang tidak merata. Faktor struktural tersebut tidak hanya berasal dari pemerintah kota, tetapi juga dari kebijakan pemerintah provinsi dan pusat.

Pertumbuhan ekonomi merupakan syarat utama dari kondisi yang diperlukan untuk mengurangi kemiskinan. Namun pertumbuhan ekonomi saja harus menjadi kondisi yang cukup untuk mengatasi masalah kemiskinan karena menciptakan tradeoff untuk dampak rata-rata. Pertumbuhan ekonomi kehilangan makna bagi kaum miskin ketika terjadi ketidakadilan, atau dengan kata lain jika manfaat pertumbuhan ekonomi tersebut lebih ditujukan kepada kaum kaya saja, bukan berpihak pada kaum miskin (Universitas Sumatera Utara, 11 Februari 2020).

Keseimbangan pertumbuhan ekonomi merupakan modal untuk meningkatkan persaingan yang sehat sehingga lembaga wakaf dapat memberikan solusi yang win-win solution untuk mengatasi permasalahan yang ada dalam kehidupan masyarakat Islam. Dilihat dari kondisi tersebut, banyak lahan wakaf di Kota Medan yang belum dimaksimalkan untuk dipergunakan dengan baik dan kurang dapat memberikan informasi kepada umat Islam, terlebih sebelum terbitnya UU No. 5 tahun 1960 tentang Ketentuanketentuan Pokok Agraria dan PP No. 28 Tahun 1977 tentang Wakaf Milik Tanah yang mengatur masalah tanah dan wakaf dengan baik dan bermanfaat. Umat Islam Medan 


\section{Kontribusi Wakaf Lahan Produktif Untuk Meningkatkan \\ Sosial-Ekonomi Masyarakat Islam Di Medan}

Mukhlis

hanya bertumpu pada hukum yang telah diturunkan Allah SWT yaitu menganggap harta wakaf adalah milik Allah SWT saja.Secara umum, tanah wakaf di Indonesia banyak digunakan untuk pendidikan, pekuburan, pembangunan masjid dan musolla. (Kementerian Agama RI, 2005)

Penggunaan wakaf yang telah diturunkan Allah SWT dan sejalan dengan UndangUndang Republik Indonesia memberikan manfaat bahwa tanah wakaf dapat digunakan untuk bidang pendidikan, pemakaman, masjid dan musala saja, namun terdapat perubahan dan pola pikir baru bahwa tanah wakaf jauh lebih mahal harganya / nilai ekonominya. Di Kota Medan, bidang pendidikan berdampak positif bagi masyarakat sekitar misalnya: Pendidikan Islam Kabupaten Medan Kota memberikan pendidikan gratis kepada anak-anak miskin setiap tahun dan bantuan uang sekolah, di dalam lingkungan sekolah diberikan kesempatan kepada masyarakat untuk berjualan dan membuka kantin di dalam lingkungan sekolah. Untuk pemakaman di Kota Medan ada beberapa orang yang mengelola pemakaman yang ditunjuk oleh lembaga wakaf dan diberikan kuasa kepada nazhir masjid, biasanya tanah wakaf yang berdekatan dengan masjid, untuk nazhir dan pengelola wakafnya mengarahkan para pekerja untuk melakukan pengelolaan pemakaman. kemudian mereka akan berurusan dengan ahli waris bila ada yang meninggal / meninggal kemudian ahli waris yang mengurusi biaya tersebut kepada pekerja yang mengurus kuburan. Disini jelas bahwa tanah wakaf dapat memberikan nilai ekonomi dan dapat menghasilkan uang.Oleh karena itu, tanah wakaf perlu dikelola secara terbuka dan produktif terhadap hal-hal yang tidak bertentangan dengan unsur kezaliman dalam pandangan Islam, berupa pengelolaan tanah wakaf.Sehingga memberikan hasil yang positif bagi masyarakat atau warga di Kota Medan.Kehidupan sosial antar masyarakat Medan memberikan dampak yang positif bagi kehidupan masyarakat lainnya. Sikap menolong orang miskin papah adalah konsep yang islami

\section{Tanah Wakaf Produktif Meningkatkan Pendapatan Ekonomi Rakyat}

Wakaf berperan aktif dalam menjalankan kegiatan ekonomi masyarakat melalui ketersediaan tempat usaha. Dengan adanya tempat jual yang dikembangkan dari hasil dana wakaf atau di atas tanah wakaf, maka meningkatkan potensi untuk melakukan kegiatan ekonomi masyarakat Islam (Asmak Ab Rahman, 2009). Pembangunan tempat penjualan sesuai dengan tanah wakaf oleh pedagang dapat melakukan kegiatan usaha seperti yang dilakukan oleh Lalita Pulungan, SH. Wakaf juga berfungsi sebagai ibadah 
sosial, yaitu sikap tanggung jawab terhadap sesama makhluk ciptaan Tuhan. Fungsi wakaf dalam bidang kemasyarakatan merupakan aset yang sangat penting dalam pembangunan masyarakat pada umumnya.Pengelolaan atau pemanfaatan harta wakaf sangat penting dalam menunjang terselenggaranya berbagai kegiatan bagi masyarakat seperti pendidikan, rumah sakit, panti asuhan, dan bidang ekonomi seperti peternakan, pertanian, perindustrian dan lain sebagainya. (Zainurni Zein \& Faridah, http: //isjd.pdii.lipi.go.id/admin/jurnal/81074253.pdf diakses 11 Februari 2020). Hasil pemanfaatan tanah wakaf produktif diarahkan untuk kebutuhan masyarakat umum khususnya bagi anak-anak miskin diberikan beasiswa untuk pendidikan dan studi lanjut, memberikan pelayanan kesehatan kepada yang kurang mampu untuk mendapatkan pelayanan rumah sakit, panti asuhan.pengasuhan, dan pembinaan untuk anak yatim piatu di kota Medan. Begitu pula dengan peningkatan perekonomian masyarakat untuk penyediaan modal usaha, pemberian subsidi silang, benih pertanian, pupuk secara merata memberdayakan usaha-usaha rumah tangga di industri kerajinan ibu-ibu.

Kehadiran wakaf produktif di masyarakat harus dipikirkan dengan matang agar dapat dirasakan manfaatnya secara langsung oleh masyarakat dan berkelanjutan. Masyarakat yang dimaksud disini bukan hanya mereka yang hidup pada waktu tertentu tetapi generasi penerus merupakan komponen dari masyarakat itu sendiri. Oleh karena itu, menjadikan wakaf produktif merupakan kewajiban yang perlu diperhatikan. (Achyar Zein 2007)

\section{Sumbangan Wakaf Tanah Produktif Bagi Tingkat Pendidikan Muslim Medan}

Wakaf dalam bidang pendidikan merupakan modal terpenting untuk menghasilkan sumber daya manusia yang berkualitas seperti ulama dan pemimpin yang berwibawa.seluruh dunia. Diantaranya adalah Universitas Cordova Andalus, al-Azhar di Mesir, Madrasah Mizamiyah di Baghdad, Universitas Islam Indonesia, Pondok Pesantren Darunnajah Indonesia, Madrasah Al-Junedi Singapura, Al-jamiah al-Islamiah di Madinah dan lainnya (Ahmad Zaki Hj. Abd. Latif et al, 2005)

Hasil wakaf adalah keuntungan finansial dari unit komersial yang didirikan oleh Badan Wakaf. Sebagian dana hasil wakaf dan hasil wakaf lainnya digunakan untuk membiayai kebutuhan perkantoran yang berhubungan langsung dengan kegiatan wakaf seperti gaji pegawai dan pengeluaran lainnya. Program pengembangan akademik dan perbaikan sistem pendidikan, juga memanfaatkan dana dari dana abadi. Manfaat lainnya 


\section{Kontribusi Wakaf Lahan Produktif Untuk Meningkatkan \\ Sosial-Ekonomi Masyarakat Islam Di Medan}

Mukhlis

adalah peningkatan Sumber Daya Manusia (SDM) Dosen melalui lembaga pendidikannya untuk melanjutkan studi program Magister dan PhD di berbagai perguruan tinggi baik di dalam maupun di luar negeri. Di kota Medan telah diterapkan penggunaan harta wakaf yaitu untuk memberikan bantuan pendidikan kepada para pelajar atau beasiswa untuk menggunakan uang studi tambahannya. Untuk sumber dana pendidikan yang diterima, secara umum berasal dari hasil penggunaan anugerah lahan produktif sebesar 45,2\% sedangkan yang terkecil berasal dari Lansia yaitu 25,9\%. Pemberian bantuan yang tepat kepada sasaran penerima seperti orang tua, karena orang tua dapat mengatur keuangan dalam rumah tangga sehingga dana bantuan wakaf produktif dan bermanfaat, peran orang tua lebih efektif dalam mengelola keuangan keluarga. Hasil pemanfaatan tanah wakaf produktif khusus di Kota Medan dilakukan dalam bentuk dan nilai finansial yang tinggi seperti penyewa ruko dan persewaan kamar kost.Untuk pendapatan mereka sendiri terkait dengan siswa yang melakukan pekerjaan paruh waktu untuk menambah pendapatan mereka untuk membiayai pembayaran uang sekolah dan kehidupan sehari-hari. Jumlah uang yang diterima dari pemberian tanah produktif untuk pendidikan menurut sebagian besar responden adalah antara Rp200.00o-Rp300.0oo yaitu 44,4\% dan dari tabel tersebut juga dapat dilihat bahwa hanya 3 responden yang menerima uang tunai di atas $\mathrm{Rp}$ 800.000 atau hanya 2,2\% Secara kumulatif, sebanyak 76,3\% di antaranya mendapatkan uang tunai di bawah Rp 400.000

\section{Tabel 5}

Pemberian lahan produktif khusus untuk pendidikan

\begin{tabular}{|l|c|c|}
\hline & Frekuensi & Peratusan (\%) \\
\hline Rp.200,000 & 21 & 15.6 \\
\hline Rp.200,001- Rp.300,000 & 60 & 44.4 \\
\hline Rp.300,001- Rp.400,000 & 22 & 16.3 \\
\hline Rp.400,001-Rp600,000 & 11 & 8.1 \\
\hline Rp.600,001-Rp.800,000 & 18 & 13.3 \\
\hline Diatas Rp.800,000 & 3 & 2.2 \\
\hline Total & 135 & 100.0 \\
\hline
\end{tabular}

Selanjutnya penggunaan uang wakaf yang 32,6\% responden menggunakannya untuk membayar biaya sekolah, 25,9\% untuk biaya penelitian dan 24,4\% lainnya dialokasikan untuk pembelian buku dan alat tulis serta biaya hidup sehari-hari sebesar 17,0\%. Dana abadi oleh kepala sekolah kepada pihak sekolah berupa pembayaran uang 
sekolah secara tunai, biaya uang penelitian kepada siswa yang menyelesaikan skripsi dan jenjang magister satu dan dua diberikan dalam bentuk beasiswa kepada mereka.

\section{Tabel 6}

Pemberian lahan produktif digunakan untuk biaya pendidikan

\begin{tabular}{|l|c|c|}
\hline & Frekuensi & Peratusan (\%) \\
\hline Uang sekolah & 44 & 32.6 \\
\hline Biaya penelitian tugas akhir & 35 & 25.9 \\
\hline Membeli buku dan alat tulis & 33 & 24.4 \\
\hline Biaya kehidupan sehari-hari & 23 & 17.0 \\
\hline Total & 135 & 100.0 \\
\hline
\end{tabular}

Dijelaskan bahwa sebanyak 17,0\% responden memanfaatkannya untuk biaya hidup sehari-hari. Pemberian bantuan dana abadi pendidikan produktif, responden menyatakan menerima bantuan dalam bentuk tunai dan non tunai sesuai dengan kebutuhannya sebesar 45,9\%. Sebanyak 17.0\% responden menggunakannya untuk masa pensiun kehidupan sehari-hari. Bantuan dana abadi pendidikan yang diberikan, responden menyatakan menerima secara tunai dan non tunai sebesar 45,9\%.

\section{Pemberian Lahan Produktif Menuju Pelayanan Kesehatan Masyarakat di Kota}

\section{Medan}

Upaya pembangunan kesehatan merupakan upaya semua pihak tanpa terkecuali baik swasta maupun pemerintah. Untuk meningkatkan kondisi kesehatan masyarakat, peran dan seluruh elemen masyarakat baik formal maupun informal saat ini merupakan syarat penting yang harus dilaksanakan oleh pemerintah dan masyarakat, harus ada saling mendukung dalam upaya mewujudkan masyarakat yang sehat. Dalam membangun jaringan kerja sama pelayanan kesehatan masyarakat yang baik, suatu negara harus memiliki peralatan pendukung baik fisik maupun sumber daya manusia. Dalam hal ini merupakan kewajiban pemerintah untuk berperan aktif dalam memperhatikan kesehatan penduduk.

Peran pemerintah dalam meningkatkan kesehatan masyarakat seperti menjaga kesehatan, pencegahan penyakit, penyembuhan penyakit dan pengendalian kesehatan dilakukan secara komprehensif, tepat dan berkelanjutan yang tertuang dengan jelas dalam undang-undang.wakaf. Terkait kesehatan 45,9\% responden menjawab pernah mendapat pelayanan kesehatan. Bahkan sebanyak 18,5\% responden lainnya menyatakan bahwa mereka mendapatkan pelayanan kesehatan secara rutin. Dan hanya 14,8\% responden yang 


\section{Kontribusi Wakaf Lahan Produktif Untuk Meningkatkan \\ Sosial-Ekonomi Masyarakat Islam Di Medan}

Mukhlis

menyatakan tidak pernah mendapatkan pelayanan kesehatan. Untuk penerimaan wakaf tanah produktif untuk kesehatan dikelompokkan kepada yang menerima hasilnya yaitu: fakir miskin, yatim piatu, pelajar. Memang benar setiap orang bisa sakit, tetapi rasa sakit sering menular di usia tua. Sehingga segala bentuk pengobatan di rumah sakit untuk fakir miskin, dhuafa, yatim piatu, pelajar, pelajar telah dilaksanakan kerjasama oleh lembaga dakwah hingga rumah sakit.

\section{Tabel 7}

Pemberian Tanah Produktif untuk Kesehatan

\begin{tabular}{|l|c|c|}
\hline & Frekuensi & Peratusan (\%) \\
\hline Pernah & 62 & 45.9 \\
\hline Sekali-kali & 28 & 20.7 \\
\hline Tidak Pernah & 20 & 14.8 \\
\hline Rutin Total & 25 & 18.5 \\
\hline \multicolumn{1}{|c|}{ Tot } & 135 & 100.0 \\
\hline
\end{tabular}

\section{Kesimpulan}

Dari penelitian diatas dapat ditarik kesimpulan tentang pelaksanaan dan pemanfaatan tanah wakaf produktif di Kota Medan yaitu: Tanah wakaf di Kota Medan memiliki nilai harga yang tinggi, pengelolaan tanah wakaf yang profesional memberikan dampak positif bagi masyarakat muslim di Kota Medan baik kehidupannya, karena hasil tanah wakaf dapat dimanfaatkan oleh masyarakat miskin. Kementerian Agama Kota Medan fokus pada pemanfaatan lahan wakaf terlantar sebagai upaya pemanfaatannya. Upaya Kementerian Agama Kota Medan merupakan langkah positif yang selalu ditunggu dan didukung oleh umat Islam di Kota Medan. Penelitian ini dilakukan untuk memberikan kontribusi yang bijaksana kepada pihak-pihak yang berkepentingan dengan lembaga wakaf, pengelola wakaf, pengawas wakaf yang harus bekerja lebih keras lagi untuk memanfaatkan harta benda masyarakat yang belum pernah bekerja seperti tanah wakaf.Pemanfaatan tanah wakaf di Kota Medan sebagaimana mestinya diusahakan dan dikelola oleh orang-orang yang jujur dan bertanggung jawab sesuai dengan atribut Rasullah SAW yang menjadi faktor kunci sukses dalam mengelola suatu usaha, guna mendapatkan nilai moral yang tinggi yaitu: Siddiq (benar dan jujur), Kepercayaan, Fatanah (pintar), dan Tabligh (Komunikatif) (Herman Kartajaya, Muhammad Syakir Sula, 2008). Dalam penelitian ini memberikan penilai positif bahwa umat Islam khususnya di kota Medan tidak akan pernah merasa sakit, lapar, bodoh dan miskin apabila penggunaan 


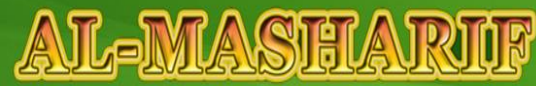

JURNAL ILMU BKONOMIDAN KBISLAMAN
Al-Masharif: Jurnal Ilmu Ekonomi dan Keislaman

Volume 8 Nomor 2 Ed. Juli - Desember 2020: hal. 189-207

p-ISSN: 2356-4628 e-ISSN : 2579-8650

harta wakaf dilakukan oleh para nazhir dengan ikhlas kepada umat Islam agar dapat melakukan fitrah Nabi SAW memberikan penilaian dan tanggapan yang positif. pemanfaatan wakaf harta benda muslim di Kota Medan.

\section{Daftar Pustaka}

A.Syafii Maarif dkk, Islam, Good Governance dan Pengentasan Kemiskinan, Kebijakan Pemerintah, Kiprah Kelompok Islam,dan Potret Gerakan Inisiatif di Tingkat Lokal, (Jakarta Maarif Institute for Culture and Humanity bekerjasama dengan The Asia Foundation 2007

Achmad Djunaidi, Menuju Era Wakaf Produktif, Sebuah Upaya Progresif Untuk Kesejahteraan Umat, 2005

Agustianto "Impact of interest on Indonesia economic downturn (case study 1997-2004)", http://www.agustiantocentre.com/?p=895 diakses 11 Februari 2020

Ahamed Kameel Mydin Meera, The Theft of Nations: Returning to Gold, Terj.Yulizar Djamaluddin Sanrego NZ, Pirates of the Nations Why Gold Should Be International Currency, Publisher Mizan 2010 cet I:

Ahmad Zaki Hj. Abd Latif dkk, "Pengurusan Harta Wakaf dan Potensinya ke arah Kemajuan Pendidikan Umat Islam di Malaysia,"dalam " (Konvensyen Wakaf Kebangsaan 2006, Wakaf Memartabatkan Kecemerlangan Ummah” Kuala Lumpur, Jabatan Wakaf Zakat dan Haji 12-14 September 2006)

Asmak Ab Rahman, Peran Wakaf dalam Perkembangan Ekonomi Umat Islam dan Aplikasinya di Malaysia, Jurnal Universitas Malaya Syariah volume 17 bil 1

Departemen Agama RI, Himpunan Peraturan Perundang-undangan Perwaqafan Tanah Milik, Projek Pembinan Zakat dan Wakaf, Jakarta,1985,91. Lihat juga Depag RI, Peraturan Perwaqafan (Waqf Regelution), Depag RI Ditjen Bimas Islam dan Urusan Haji Diktorat Urusan Agama Islam, 1998, 2 Lihat juga, Departemen Agama RI, Waqaf Tunai dalam Perspektif Islam, Penerbit, Derektorat Jenderal Bimbingan Mayarakat Islam dan Penyelenggaraan Haji, Direktorat Pengembangan Zakat dan Wakaf, 2005)

Departemen Agama RI, Wakaf Tunai dalam Perspektif Hukum Islam, Derektorat Jenderal Bimbingan Mayarakat Islam dan Penyelenggaraan Haji, Direktorat Pengembangan Zakat dan Wakaf, 2005)

Devy putra, http://putracenter.net/4-penyebab-krisis-ekonomi-indonesia-tahun-19971998-apakah-akan-terulang-pada-krisis-ekonomi-sekarang/ di akses 11 Februari 2020 
Herman Kartajaya, Muhammad Syakir Sula, SyariahMarketing, (Jakarta: Penerbit Mizan, 2008),

https://medan.tribunnews.com/2018/02/05/tahun-2017-ekonomi-sumut-sebesar-512peres diakses 11 Februari 2020

https://medankota.bps.go.id/statictable/2017/o1/17/35/jumlah-penduduk-dan-lajupertulatan-penduduk-menurut-kecamatan-di-kota-medan-2010-2014-dan2015.html diakses 11 Februari 2020

Kementerian Agama Republik Indonesia, Bunga Rampai Perwakafan, Direktorat Jenderal Bina Umat Islam tentang Pemberdayaan Wakaf 2006

Kementerian Agama Republik Indonesia, Klasifikasi Penggunaan Tanah Wakaf di Sumatera Utara dan Kalimantan, (Jakarta: Direktorat Pengembangan dan Pemberian Zakat Dirjen Bimas Islam dan Penyelenggara Haji 2005)

Kementerian Agama Republik Indonesia, Kumpulan Peraturan Legislatif tentang Pemberian Hak Milik Tanah, Proyek Pengembangan Zakat dan Wakaf, Jakarta, 1985,91 Lihat juga Kementerian Agama, Wakaf Regelusi, Kementerian Indonesia Direktorat Jenderal Urusan Islam dan Diktator Haji Urusan Islam, 1998, 2 Lihat juga, Kementerian Agama

Kementerian Agama Republik Indonesia, Strategi Pengamanan Tanah Wakaf, (Jakarta: Penerbit Proyek Peningkatan Pemberdayaan Wakaf (Jakarta: Direktur Jenderal Administrasi Haji dan Haji Kementerian Agama Islam Republik Indonesia 2004) Pemberdayaan Wakaf

Muhammad Yasir Nasution, "Konstruksi Fiqh Waqf Berwawasan Ekonomi Syari'ah, Istislah, Jurnal Hukum Islam, Ekonomi dan Kemasyarkatan, Vol I no.2 (April-Jun 2002),

Mundir Qahaf, Manajemen Wakaf Produktif, diterjemahkan oleh H. Muhayiddin Mas Ridam Lc, Penerbit, KHALIFA Jakarta Cet 12004.

Nik Mustafa Haji Nik Ahmad, Wakaf Konsep dan Implementasi Seminar (Kuala Lumpur, Penerbit yang Diselenggarakan oleh Institut Pemahaman Islam Malaysia (IKIM) Perusahaan Pengembangan Waqaf Malaysia dan Institut Penelitian dan Pelatihan BIMB .Sdn.Bhd (BIRT) 1999.

Republik Indonesia, Uang Tunai Wakaf dalam Perspektif Islam, Penerbit, Direktorat Jenderal Pembinaan dan Pemeliharaan Umat Islam Haji, Direktorat Pengembangan Zakat dan Wakaf, 2005)

Undang-Undang No 23 Tahun 1992 tentang Kesehatan https://www.balitbangham.go.id/pocontent/peraturan/uu.\%20no\%2023\%20tahun\%201992\%20tentang\%2okesehatan .pdf di akses 24 Februari 2020 
Universiti Sumatera Utara, Makalah di upload 11 Februari 2020 http://repository.usu.ac.id/bitstream/123456789/28086/4/Chapter\%20I.pdf

Zainurni Zein \& Faridah, Pemanfaatan Tanah Wakaf di Kota Padang, http://isjd.pdii.lipi.go.id/admin/jurnal/81074253.pdf diakses 11 Februari2020 